Have you ever seen a mirage and marvelled at its strange beauty? It is usually in the autumn when all the stmospheric conditions are favourable, that these strange illusions take place on the prairie ocean.

Early in the morning just before the red disc of the sun peers above the horizon-line, one may see inverted in the sky the landscape of trees, waving grass, grain, rocks and hills, held together, as it were by the threads of yellow, and grey and azure.

Occasionally an object appears in mïsty or foggy weather, especially on water, where it is magnified both vertically and horizontally which gives rise to the phenomena. known as "looming."

On tarred roads, one frequently sees the sky reflected in the form of a shimmering lake.

Perhaps one of the most interesting references to the prairie mirage is found in J.W. Winkley's "John Brown, the Hero." He relates how a horseman, who had been riding full speed up the creek one morning in 1856, stopped at their cabin door. The horseman brought the news that the Ruffians were over the border, upon them again, in strong force. He was a messenger from the Middle River region and had been despatched to them by their comrades in distress. His mission was, of course, to secure help. The need was urgent. As the speaker drew his narration to a close, all present instinotively turned their eyes in the dircetion whence he had come: namely toward the south-east. There a sight met their gaze that riveted them to the spot - a spectacle as marvelous as it was beautiful, and confimatory in every detail to the informer's words. To their utter astonishment, they looked, at that moment, directly into the enemy's camp twenty miles away, though seemingly less than quarter of that distance.

The camp was mirrorer perfectly and beautifully against the sky. With the aid of military field glasses, every feature in detail could be traced: the early risers moving through the camp-ground, the horses standing patiently outside, awaiting their morning meal; the positions of the pickets keeping guard. Even the curling smoke of the newly kindled campfire, as it ascended upward, curiously traced itself visibly to the eye.

The groundwork of this illusion is grayish, semi-opaque mist and the objects are seen standing or moving along in it. The feet of animals and of men, the trunks of trees, the rocks and hillocks, are set in this aqueous soil. When conditions are perfect, objects far beyond the range of vision over the prairie are brought near and into plain $\nabla i \in w$ of the beholder.

Many different types of mirage have been observed on land, sea, mountains and even from aeroplanes. If you have not yet observed a mirage, watch for one, then linger a while, and drink from the cup of nature; gaze upon it in wonderment until it vanishes before your eyes.

\title{
- - - - -
}

\section{THE RABBITS QUADRIIIE}

Deep in moonlit winter woods, When hooting owls are still,

In a snowy clearing

Rabbits dance quadrilles.
The pine tree is the violin, The north wind is the bow,

But who the music mastor is I'm sure I do not know.

The rabbits, in their places all,

Gaily leap and prance.

I think it was the fairies

Taught the rabbits how to dance.

- Annie Law Bennett, Dorintosh, Saskatchewan. 